\title{
COMPARATIVE ANALYSIS : WORKING CAPITAL EFFICIENCY MANUFACTURING COMPANIES LISTED ON INDONESIAN STOCK EXCHANGE
}

\author{
NURLAELA \\ University of Muslim Maros \\ nurlaelanais@gmail.com \\ Paper ID : 27-1-4-20180324
}

\begin{abstract}
ABSTRACK
This study aims to determine which companies are more efficient use of working capital between PT. Mayora Indah Tbk. and PT. Siantar Top Tbk. Method analysis is descriptive with the analysis of financial ratios used are the ratio of activities of asset turnover, inventory turnover, and working capital turnover. Results of research that PT. Mayora Indah Tbk. activity ratio of the asset turnover is 6.59 times, inventory turnover is 23.87 times, and the working capital turnover is 18.07 times and PT. Siantar Top Tbk. asset turnover ratio of 5.9 times, inventory turnover 27.78 times, and turnover of working capital -910.71 times. Both companies are then PT. Mayora Indah Tbk. more efficient use of working capital than PT. Siantar Top Tbk. which is listed on the Indonesia Stock Exchange.
\end{abstract}

Keywords: Working Capital, Efficiency, Comparative Analysis

\section{INTRODUCTION}

The more extensive the services provided plus the increasingly tight competition now, according to the good working capital management from the management in order to guarantee the continuity of business in the future. For a working capital company is a necessity that requires great attention and careful action in its management. Therefore, the task of managers of a company is to plan the future and smoothen the company's operations so as to achieve the goal of achieving maximum profit and the company's survival. The fact shows that the time of big financial managers is devoted to the daily internal work. One measure often used to assess the success or failure of financial managers in carrying out their duties is in terms of management of working capital management because working capital management is closely related to daily business activities and business survival. Funds required by the company to finance its daily operations are called working capital. Working capital is an investment company in the form of cash, accounts receivable, inventory and other assets including current.

Working capital is one of the most important asset elements in a company. Because without working capital the company can not meet the need for funds to run its activities. The period of working capital turnover since cash invested in the elements of working capital to cash again, is less than a year or short term. The period of working capital turnover shows the level of efficiency of the use of working capital. The faster the working capital turnover the more efficient the use of working capital, and of course the

DOI : 10.3828/IJEMSS/v1i1.5

VOLUME 1 ISSUE 1 MARCH 2018

http://journals..salewangang.org/ojs/index.php/IJEMSS/index

Licensed Under Creative Commons Attribution 4.0 
investment in working capital is getting smaller. Therefore, financial managers are required to manage the working capital well thus increasing the efficiency of working capital. Working capital is an important issue and an important topic that is often faced by the company, because working capital and current assets is a large part of the assets, so the company is required to always improve work efficiency so as to achieve goals expected by the company that is to achieve optimal profit.

Similarly, PT. Mayora Indah Tbk and PT. Siantar Top Tbk is two open companies engaged in the food industry. Both companies are large food companies have good quality and performance so that can be compared with each other in seeing how the management of working capital, whether the management of working capital owned has been managed properly so as to improve the efficiency of the use of funds in each company, the second the competing company can be a company to date.

\section{MATERIAL AND METHOD}

This research was conducted at Indonesian Stock Exchange. This research is using comparative descriptive analysis method with financial ratio analysis, where the financial ratios used in this research is ratio activity. Total Assets Turnover, Inventory Turnover and Working Capital Turnover. Population of research is manufacturing companies. Sample of this research is PT. Mayora Indah Tbk and PT. Siantar Top Tbk.

\section{RESULT AND DISCUSSION}

Table 1 it can be seen that asset turnover of PT Mayora Indah, Tbk in 2012 until the year 2016 fluctuated, this is because sales are not too increased compared to total assets.

Table 1. Sales and Total Assets PT. Mayora Indah Tbk (2012-2016)

\begin{tabular}{ccc}
\hline Year & \multicolumn{1}{c}{ Sales } & \multicolumn{1}{c}{ Total Assets } \\
\hline 2012 & 9.453 .865 .992 .878 & 6.599 .945 .533 .328 \\
2013 & 10.510 .625 .669 .832 & 8.302 .506 .241 .903 \\
2014 & 12.017 .837 .133 .337 & 9.709 .838 .250 .473 \\
2015 & 14.169 .088 .278 .238 & 10.297 .997 .020 .540 \\
2016 & 14.818 .730 .635 .847 & 11.342 .715 .696 .221 \\
\hline
\end{tabular}

Table2. Total Assets Turnover PT. Mayora Indah Tbk (2012-2016)

\begin{tabular}{cccc}
\hline Year & Turnover & Percentage & Growth \\
\hline 2012 & 1,43 & 21,70 & 0 \\
2013 & 1,26 & 19,12 & 0,17 \\
2014 & 1,23 & 18,66 & 0,03 \\
2015 & 1,37 & 20,79 & 0,14 \\
2016 & 1,30 & 19,73 & 0,07 \\
\hline Total & 6,59 & 100 & 0,41
\end{tabular}

Table 4 Inventory Turnover PT. Mayora Indah Tbk, fluctuated from 2012 to 2016 . This

is due to declining sales while inventories increase.

DOI : 10.3828/IJEMSS/v1i1.5

VOLUME 1 ISSUE 1 MARCH 2018

http://journals..salewangang.org/ojs/index.php/IJEMSS/index

Licensed Under Creative Commons Attribution 4.0 
Table 3. Sales and Inventory PT. Mayora Indah Tbk (2012-2016)

\begin{tabular}{ccl}
\hline Year & Cost of Goods Sold & \multicolumn{1}{c}{ Average Inventory } \\
\hline 2012 & 7.795 .454 .967 .722 & $917.357 .173 .261,5$ \\
2013 & 8.165 .009 .551 .392 & $1.417 .619 .789 .154,5$ \\
2014 & 9.096 .171 .291 .553 & 1.477 .721 .837 .627 \\
2015 & 11.633 .862469 .470 & 1.711 .627 .426 .633 \\
2016 & 10.620 .394 .515 .840 & $.865 .016 .846 .173,5$ \\
& & \\
\hline
\end{tabular}

Table 4. Inventory Turnover PT. Mayora Indah Tbk (2012-2016)

\begin{tabular}{cccc}
\hline Year & Turnover & Percentage & Growth \\
\hline 2012 & 8,49 & 25,83 & 0 \\
2013 & 5,75 & 17,49 & 2,74 \\
2014 & 6,15 & 18,71 & 0,4 \\
2015 & 6,79 & 20,66 & 0,64 \\
2016 & 5,69 & 17,31 & 1,1 \\
\hline Total & 32,87 & 100 & 4,88 \\
\hline
\end{tabular}

Table 6 working capital turnover fluctuates from 2012 to 2016 . This is due to

increased sales while working capital decreases.

Table 5. Sales and Working Capital PT. Mayora Indah (2012-2016)

\begin{tabular}{cccc}
\hline Year & Net Sales & Current Assets & Current Liabilities \\
\hline 2012 & 9.453 .865 .992 .878 & 4.095 .298 .705 .091 & 1.845 .791 .716 .500 \\
2013 & 10.510 .625 .669 .832 & 5.313 .599 .558 .516 & 1.924 .434 .119 .144 \\
2014 & 12.017 .837 .133 .337 & 6.430 .065 .428 .871 & 2.631 .646 .469 .682 \\
2015 & 14.169 .088 .278 .238 & 6.508 .768 .623 .440 & 3.114 .337 .601 .361 \\
2016 & 14.818 .730 .635 .847 & 7.454 .347 .029 .087 & 3.151 .495 .162 .694 \\
\hline
\end{tabular}

Table 6. Working Capital Turnover PT. Mayora Indah Tbk (2012-2016)

\begin{tabular}{cccc}
\hline Year & Turnover & Percentage & Growth \\
\hline 2012 & 4,20 & 23,24 & 0 \\
2013 & 3,10 & 17,15 & 1,1 \\
2014 & 3,16 & 17,49 & 0,06 \\
2015 & 4,17 & 23,08 & 1,01 \\
2016 & 3,44 & 19,04 & 0,73 \\
\hline Total & 18,07 & 100 & 2,9 \\
\hline
\end{tabular}

DOI : 10.3828/IJEMSS/v1i1.5

VOLUME 1 ISSUE 1 MARCH 2018

http://journals..salewangang.org/ojs/index.php/IJEMSS/index

Licensed Under Creative Commons Attribution 4.0 
Table 8 Total Assets Turnover PT Siantar Top Tbk 2012 until 2016 fluctuate.
This is because sales increase more than asset turnover.

Table 8. Total Assets Turnover PT. Siantar Top Tbk (2012-2016)

\begin{tabular}{cccc}
\hline Year & Turnover & Percentage & Growth \\
\hline 2012 & 1,09 & 18,63 & 0 \\
2013 & 1,02 & 17,44 & 0,07 \\
2014 & 1,15 & 19,66 & 0,13 \\
2015 & 1,27 & 21,71 & 0,12 \\
2016 & 1,32 & 22,56 & 0,05 \\
\hline Total & 5,85 & 100 & 0,37 \\
\hline
\end{tabular}

Table 10 Inventory Turnover PT Siantar Top Tbk from 2012 to 2016 has fluctuated.
This is because more sales increase compared to inventory.

Table 10. Inventory Turnover PT. Siantar Top Tbk (2012-2016)

\begin{tabular}{|c|c|c|c|}
\hline Year & Turnover & Percentage & Growth \\
\hline 2012 & $-65,43$ & 7,18 & 0 \\
\hline 2013 & $-881,39$ & 96,78 & 815,96 \\
\hline 2014 & 19,87 & $-2,18$ & $-901,26$ \\
\hline 2015 & 8,32 & $-0,91$ & 11,55 \\
\hline 2016 & 7,92 & $-0,87$ & 0,4 \\
\hline Total & $-910,71$ & 100 & $-73,35$ \\
\hline
\end{tabular}

Comparative analysis Working Capital PT. Siantar Top Tbk and PT. Mayora Indah Tbk

PT. Mayora Indah Tbk. has activity ratios that is asset turnover 6.59 times, while
PT. Siantar Top Tbk. in the activity ratio of asset turnover is 5.9 times for five Years.

Table 11. Assets Turnover PT. Siantar Top Tbk and PT Mayora Tbk

\begin{tabular}{ccc}
\multicolumn{2}{c}{ Year } & \multicolumn{2}{c}{ Assets Turnover } \\
\cline { 2 - 3 } & PT. Mayora Indah & PT. Siantar Top \\
\hline 2012 & 1,43 & 1,09 \\
2013 & 1,26 & 1,02 \\
2014 & 1,23 & 1,15 \\
2015 & 1,37 & 1,27 \\
2016 & 1,30 & 1,32 \\
Total & 6,59 & 5,9 \\
\hline
\end{tabular}

PT. Mayora Indah Tbk. has activity ratios, inventory turnover is 23.87 times, while

DOI : $10.3828 / \mathrm{IJEMSS} / \mathrm{v} 1 \mathrm{i} 1.5$

VOLUME 1 ISSUE 1 MARCH 2018

http://journals..salewangang.org/ojs/index.php/IJEMSS/index

Licensed Under Creative Commons Attribution 4.0 
PT. Siantar Top Tbk. in the ratio of activity five years. that is the turnover of supplies 27.78 times in

Table 12. Inventory Turnover PT. Siantar Top Tbk and PT. Mayora Tbk

\begin{tabular}{ccc}
\multicolumn{2}{l}{ Year } & \multicolumn{2}{c}{ Inventory Turnover } \\
\cline { 2 - 3 } & PT. Mayora Indah & PT. Siantar Top \\
\hline 2012 & 8,49 & 5,52 \\
2013 & 5,75 & 5,12 \\
2014 & 6,15 & 5,24 \\
2015 & 6,79 & 5,29 \\
2016 & 5,69 & 6,61 \\
\hline Total & 32,87 & 27,78 \\
\hline
\end{tabular}

PT. Mayora Indah Tbk. has activity ratios that is working capital turnover 18.07 times, while PT. Siantar Top Tbk. in activity ratio that is working capital turn $-910,71$ times for five year.

Table 13. Working Capital Turnover PT. Siantar Top Tbk and PT. Mayora Tbk

\begin{tabular}{crc}
\hline \multicolumn{2}{l}{ Year } & \multicolumn{2}{c}{ Working Capital Turnover } \\
\cline { 2 - 3 } & PT. Mayora Indah & PT. Siantar Top \\
\hline 2012 & 4,20 & $-65,43$ \\
2013 & 3,10 & $-881,39$ \\
2014 & 3,16 & 19,87 \\
2015 & 4,17 & 8,32 \\
2016 & 3,44 & 7,92 \\
\hline Total & 18,07 & $-910,71$ \\
\hline
\end{tabular}

The comparison table is PT. Mayora Indah Tbk. has a greater activity ratio than PT. Siantar Top Tbk, while PT. Siantar Top Tbk. has no advantage due to the decreasing working capital turnover. Hypothesis in this study is accepted that PT. Mayora Indah Tbk. more efficient use of working capital than PT. Siantar Top Tbk.

\section{CONCLUSION}

Ratio activity are asset turnover 6.59 times, inventory turnover 23.87 times, and working capital turnover 18.07 times indicates that the turnover rate of activity ratios of $P T$.
Mayora Indah Tbk. tend to increase more than PT. Siantar Top Tbk. PT. Siantar Top Tbk. in asset turnover ratio is 5.9 times, supply turnover is 27.78 times, and working capital turn -910,71 times has no advantage due to excess funds invested in assets and inventory while turnover of working capital decreases. So it can be concluded that PT. Mayora Indah Tbk. more efficient use of working capital than PT. Siantar Top Tbk. From 2012 to 2016.

DOI : $10.3828 /$ IJEMSS/v1i1.5

VOLUME 1 ISSUE 1 MARCH 2018

http://journals..salewangang.org/ojs/index.php/IJEMSS/index

Licensed Under Creative Commons Attribution 4.0 


\section{REFERENCE}

Brigham, F, Eugene and Houston, F, Joel. (2001), Manajamen Finance. Jakarta: Erland.

Ernawati Fitri. (2014), Efficiency Analysis of Working Capital at KUD Margomulyo In Jatiyoso, Karanganyar. Muhammadiyah Surakarta university.

Halaim and Sarwoko (2010), Financial Management. Issue 2. Yogyakarta.

Handoko T. Hani. (2000), Fundamentals of Production and Operations Management. Yogykarta: BPFE.

Harahap Sofyan. (2001), "Critical Analytical on Financial Statements". Third Print. PT Rajagrafindo Persada. Jakarta.

Jumaingan. (2006), Financial Statement Analysis, Jakarta: PT. Earth Script.

Karim Adiwarman. (2004), Fiqh and Financial Analysis. Jakarta: Raja Grafindo.

Cashmere. (2011), Financial Statement Analysis, PT. Raja Grafindo, Jakarta

Machmu Sella. (2015), Comparative Analysis of Working Capital Turnover In Food And Beverage Industry Companies Listed In IDX. Sam Ratulangi University of Manado. Journal of Emba.
Mamduh and Hanafi. (2009), Financial Management. Issue 1. BPFE. Yogyakarta.

Munawir, S. (2010), Financial Statement Analysis. Liberti: Yogyakarta

Prastowo Dwi and Julianti Rifka. (2002), Financial Statement Analysis. Yogyakarta: UPP AMP YPKN.

Riyanto Bambang. (2010), Fundamentals of Company Spending. Yogyakarta: BPFE.

Rodoni. (2010), Financial Management. Jakarta: Mitra Wacana Media

Rumui Jovita Devina. (2011), Comparative Analysis of Working Capital as a Means to Improve Efficiency of Fund Usage Between PT. Indofood Sukses Makmur Tbk And PT. Mayora Indah Tbk.

Sartono Agus (2010), Financial Management. Yogyakarta: BPFE.

Srir Agnes. (2005), Funding and Restructuring Policy. Jakarta: PT. Gramedia Pustaka.

Syamsuddin Lukman. (2009), Corporate Financial Management. Jakarta: PT Rajagrafindo Persada.

DOI : 10.3828/IJEMSS/v1i1.5

VOLUME 1 ISSUE 1 MARCH 2018

http://journals..salewangang.org/ojs/index.php/IJEMSS/index

Licensed Under Creative Commons Attribution 4.0 
Single Widjaja. (2000), Fundamentals of Financial Statement Analysis.

Yogyakarta: PT. Rineka Cipta 